\title{
Effect of Supplementing Area Specific Mineral Mixture on Reproductive Performance of Peripartum Black Bengal Goats
}

\author{
G.M. Kedare ${ }^{1 *}$, Vipin $^{2}$, R.S. Mantri ${ }^{1}$, A. Mandal ${ }^{1}$, M. Karunakaran ${ }^{1}$ and M.K. Ghosh ${ }^{1}$ \\ ${ }^{1}$ ICAR-National Dairy Research Institute, Eastern Regional Station, \\ Kalyani-741 235, West Bengal, India \\ ${ }^{2}$ Division of Animal Nutrition-Indian Veterinary Research Institute, \\ Bareilly, Uttar Pradesh, India \\ *Corresponding author
}

\section{A B S T R A C T}

\begin{tabular}{|c|}
\hline Keywords \\
\hline $\begin{array}{l}\text { Area specific } \\
\text { mineral mixture, } \\
\text { Reproduction, } \\
\text { Peripartum, Black } \\
\text { Bengal does }\end{array}$ \\
\hline Article Info \\
\hline $\begin{array}{l}\text { Accepted: } \\
\text { 05 April } 2020 \\
\text { Available Online: } \\
10 \text { May } 2020\end{array}$ \\
\hline
\end{tabular}

The deficiency of each mineral in animal results in various health disorders that can be removed by supplementation of suitable specific mineral. This study was conducted to find out the influence of area-specific mineral mixture supplementation on reproductive performances during peripartum period in Black Bengal does with a birth weight of the kid, first postpartum heat, conception rate, hormones (Progesterone and Estradiol-17 $\beta$ ). For this purpose, two groups of 20 pregnant Black Bengal does were made into according to the body weights viz., Control- $\mathrm{T}_{0}(\mathrm{~N}=10)$ and Treatment- $\mathrm{T}_{1}(\mathrm{~N}=10)$ supplemented with 0 and $6 \mathrm{~g} \mathrm{ASMM/animal/day,} \mathrm{respectively} \mathrm{starting} \mathrm{from} 3$ months before the expected date of parturition to till the onset of first post-partum estrus. Overall mean birth weight of kid born and mean average placental weight in control $\left(\mathrm{T}_{0}\right)$ and treatment $\left(\mathrm{T}_{1}\right)$ group were statistically non-significant $(\mathrm{P}>0.05)$ between the groups. The onset of first postpartum heat and conception rate after first postpartum heat in control $\left(\mathrm{T}_{0}\right)$ and treatment $\left(\mathrm{T}_{1}\right)$ groups were non-significant $(\mathrm{P}>0.05)$ between the groups. Overall mean plasma estradiol$17 \beta(22.34 \pm 0.26$ vs. $23.13 \pm 0.30 \mathrm{pg} / \mathrm{ml})$ and progesterone $(5.96 \pm 0.17 \mathrm{vs} .7 .22 \pm 0.17 \mathrm{ng} / \mathrm{ml})$ were significant $(\mathrm{P}<0.05)$ between groups. So, the supplementation of the area-specific mineral mixture improved the reproductive performances of Black Bengal does.

\section{Introduction}

The goat breed Black Bengal goat (Capra hircusbengalensis) is mostly found in the Eastern and North-Eastern region of India. It is a small size, highly prolific and meat-type breed of goat and it has many desirable traits like sexual maturity at an early age (6-8 months). There are important twenty-two mineral elements which are very much essential for animals. Animal health and production are influenced by these minerals within the body (Sharma et al., 2009). Trace elements are often correlated with reproductive efficiency in animals. Trace elements affect the several enzymatic 
activities in the body so they can reduce reproductive efficiency including cessation of cyclic activity. Many nutritional factors can affect reproduction. Reports indicated that micronutrient deficient can alter the serum progesterone and oestrogen level of animals (Kumar et al., 2005). Lower concentration of micronutrients causes conception failure and embryonic death one of the most important reason for repeat breeding in cattle. Reproductive failure accounts for nearly50 per cent of all losses resulting from disease, mostly due to mineral deficiency. In this manner, there is an abundant opportunity for exploiting the idea of area-specific mineral mixture for adjusting the deficiency/excess of minerals for extract the ideal production potential of animals to improve the economy of farmers. Ghosh et al., (2013) reported six minerals are deficient in lower Gangetic part of West Bengal namely $\mathrm{Ca}, \mathrm{P}, \mathrm{Zn}, \mathrm{Cu} \mathrm{Co}$ and $\mathrm{Mn}$ but till now, the impacts of the areaspecific mineral mixture have not been studied on reproductive performance of Black Bengal goat.

\section{Materials and Methods}

This study was approved by the Institutional Ethics Committee of the National Dairy Research Institute, India.

Site, selection and feeding trial of experimental animals

All experimental animals were 20 Black Bengal does of $1^{\text {st }}$ parity maintained at E.R.SI.V.R.I. Kalyani farm. Animals were divided randomly based on their body weight into two groups control $\left(\mathrm{T}_{0}\right)$ and treatment $\left(\mathrm{T}_{1}\right)$ based on initial body weight so that the average body weights of the two groups were similar. In the morning time, measured quantity (300 g per animal per day) of concentrate feed was given to each animal individually. In control (T0) group, no area-specific mineral mixtures were fed, whereas in treatment group experimental animal was fed with areaspecific mineral mixture @ 6g per animal per day starting from three months before parturition to till first post-partum estrus shown by the animals. The area-specific mineral mixture (KALMIN- ERS) used to fed the experimental goat has the following composition.

\section{Chemical analysis}

Chemical analysis of the following parameters was done as per AOAC (2005) and fractions of cell wall constituents such as NDF, ADF, cellulose, hemicellulose and lignin were estimated as per Van Soest et al., (1991).

\section{Estimation of blood hormones}

Blood samples were collected from all the animals at fortnightly interval started from three months before parturition till up to first post-partumestrus for estimation of plasma progesterone and oestrogen.

Blood was collected from the jugular vein and collected in the heparin-coated vial after that plasma was collected from each sample by centrifuge machine. Oestrogen and progesterone were estimated by using a commercially available ELISA Kit. For estrogen bovine ELISA Kit Catalog number E0004Bo and for bovine progesterone ELISA Kit Catalog number E0018 Bowas Used.

\section{Statistical analysis}

Suitable statistical procedures were followed to the analysis of data recorded under various experiments in this study. Different statistical designs were considered to the analysis of data as per Snedecor and Cochran (1994) and analysis through SPSS programme. 


\section{Results and Discussion}

The area-specific mineral mixture (KALMIN ERS) was fed to pregnant Black Bengal does to study its effects on reproductive performance of pregnant Black Bengal doe.

\section{Chemical composition of experimental ration}

The same experimental ration except ASMM for the treatment group was fed to pregnant Black Bengal does. Chemical composition of concentrate mixtures and green fodder is presented in Table 2.

\section{Influence of ASMM on birth weight of kid}

The present study revealed that kids weight did not differ significantly $(\mathrm{P}>0.05$; Table 4$)$ in between the groups. Several authors (Husain, 1999; Amin et al., 2001) reported that male kids have more birth weight than female kids. The average birth weight of crossbred goat and black Bengal goats were $1.90 \pm 0.75$ and $1.60 \pm 0.50$ respectively and differences were statistically $(\mathrm{P}<0.05)$ significant Under the traditional farming system of sub-continent, the birth weights of kids were $1.5 \mathrm{~kg} \& 2.0 \mathrm{~kg}$ respectively (Banerjee, 2004).

\section{Influence of ASMM on placental weight}

The present study revealed that placental weight did not differ significantly $(\mathrm{P}>0.05$; Table 4) in between the groups. Harrison and Hancock (1984) reported that Se supplementation (as oral or injected) reduced the incidence of RFM in about 80 per cent of studies. Placental weight of Black Bengal does was found to be $175.0 \pm 12.3,187.5 \pm 15.6$, $230.0 \pm 11.5,197.5 \pm 13.7$ on supplementation of different level of concentrate mixture viz. $150,200,250$ and $300 \mathrm{~g} /$ day respectively by Sultanaet.al.(2012). Placental weight is mainly influenced by the litter size (Hafez, 1962).

\section{Influence of ASMM on first post-partum heat}

In our present study, it is being observed that in treatment $\left(T_{1}\right)$ group most of the animal have come on first post-partum heat in early days, whereas in control groups first postpartum heat come in late but did not differ significantly ( $P>0.05$;Table 4$)$ between the groups. Estrus signs were observed in the groups by observing some visual signs like oedema of the vulva, congestion of mucous membrane and presence of mucus discharge. Verma et al., (2015) reported that age at first estrus significantly $(\mathrm{P}<0.05)$ lower in ASMM fed heifers. In copper-deficient animals, low fertility relatedto suppressed estrus. (Smith and Akinbamijo, 2000; Underwood and Suttle, 2003). Kreplinand Yaremcio (1992) observed that low fertility in animals related to delayed or suppressed estrus that grazed on $\mathrm{Cu}$ deficient pastures.

\section{Influence of ASMM on conception rate at first post-partum estrus}

It is one important parameter to measure reproductive efficiency. It is also called the conception rate. The overall mean of conception rate in the first post-partum heat was $60 \%$ inthe control group and $80 \%$ in the treatment group, respectively (Table 4 ).

Ballantine et al., (2002) reported the same improvements with the organic form to replaced inorganic sulphate salts of Copper, Manganese, Zinc and Cobalt. 
Table.1 Composition of Area Specific mineral mixture (ASMM) fed to Goats during the study (in each 100 gram)

\begin{tabular}{|c|c|}
\hline Minerals & Quantity (gram) \\
\hline Calcium & 25.96 \\
\hline Phosphorus & 20.08 \\
\hline Zinc & 0.529 \\
\hline Copper & 0.258 \\
\hline Cobalt & 0.027 \\
\hline Manganese & 0.011 \\
\hline
\end{tabular}

Table.2 Chemical composition of concentrate and green fodder feed to the experimental animals in \% DM basis

\begin{tabular}{|c|c|c|}
\hline Parameter & Concentrate & Green fodder \\
\hline Dry Matter (DM) & $93.9 \pm 0.12$ & $17.13 \pm 2.33$ \\
\hline Organic Matter (OM) & $93.72 \pm 0.07$ & $86.81 \pm 0.63$ \\
\hline Crude Protein (CP) & $18.94 \pm 0.60$ & $12.82 \pm 1.73$ \\
\hline Ether Extract (EE) & $4.51 \pm 0.10$ & $2.66 \pm 0.27$ \\
\hline Total Ash (TA) & $6.28 \pm 0.07$ & $12.92 \pm 0.62$ \\
\hline Acid Insoluble Ash (AIA) & $1.77 \pm 0.06$ & $3.36 \pm 0.28$ \\
\hline Neutral Detergent Fiber (NDF) & $32.54 \pm 1.67$ & $57.6 \pm 5.65$ \\
\hline Acid Detergent Fiber(ADF) & $11.20 \pm 1.98$ & $35.91 \pm 4.08$ \\
\hline
\end{tabular}

Table.4 Influence of ASMM on reproductive performance of Black Bengal does

\begin{tabular}{|c|c|c|c|c|c|}
\hline Groups & $\begin{array}{c}\text { No. of animal } \\
\text { conceive }\end{array}$ & $\begin{array}{c}\text { The onset of } \\
\text { first post- } \\
\text { partum heat } \\
\text { (days) }\end{array}$ & $\begin{array}{c}\text { Conception } \\
\text { rate first post- } \\
\text { partum heat }\end{array}$ & $\begin{array}{c}\text { Birth } \\
\text { weight } \\
\text { (kg) of kid }\end{array}$ & $\begin{array}{c}\text { Placental } \\
\text { weight (gm.) }\end{array}$ \\
\hline Control $\left(\mathbf{T}_{\mathbf{0}}\right)$ & 6 & $36.6 \pm 4.59$ & $\mathbf{6 0 \%}$ & $1.05 \pm 0.05$ & $224.89 \pm 4.19$ \\
\hline $\begin{array}{c}\text { Treatment } \\
\left(\mathbf{T}_{\mathbf{1}}\right)\end{array}$ & 8 & $30.9 \pm 3.38$ & $\mathbf{8 0 \%}$ & $1.07 \pm 0.04$ & $232.6 \pm 6.02$ \\
\hline
\end{tabular}

Table.5 Plasma estradiol-17 $\beta(\mathrm{pg} / \mathrm{ml})$ profile of black Bengal does

\begin{tabular}{|c|c|c|c|c|c|c|c|c|c|c|c|c|c|c|}
\hline \multirow[t]{2}{*}{ Group } & \multicolumn{13}{|c|}{ Days interval } & \multirow{2}{*}{$\begin{array}{c}\text { Mean } \\
\pm \\
\text { SEM }\end{array}$} \\
\hline & -90 & -75 & -60 & 45 & -30 & -15 & O & 15 & 30 & 45 & 60 & 75 & 90 & \\
\hline $\begin{array}{c}\text { Control } \\
\left(\mathrm{T}_{0}\right)\end{array}$ & $\begin{array}{c}21.87 \pm \\
0.24\end{array}$ & $\begin{array}{c}22.11 \pm \\
0.31\end{array}$ & $\begin{array}{c}20.22 \pm \\
0.44\end{array}$ & $\begin{array}{c}21.42 \pm \\
0.29^{\mathrm{b}}\end{array}$ & $\begin{array}{c}22.87 \pm \\
0.18^{\mathrm{b}}\end{array}$ & $\begin{array}{c}23.62 \pm \\
0.15^{\mathrm{b}}\end{array}$ & $\begin{array}{l}25.0 \pm \\
0.22^{\mathrm{b}}\end{array}$ & $\begin{array}{c}22.9 \pm \\
0.22\end{array}$ & $\begin{array}{c}22.6 \pm \\
0.27\end{array}$ & $\begin{array}{c}21.7 \pm \\
0.22\end{array}$ & $\begin{array}{c}22.1 \pm \\
0.25\end{array}$ & $\begin{array}{c}21.9 \pm \\
0.29\end{array}$ & $\begin{array}{c}21.88 \pm \\
0.30\end{array}$ & $\begin{array}{c}22.34 \pm \\
0.26^{\mathrm{b}}\end{array}$ \\
\hline $\begin{array}{c}\text { Treatment } \\
\left(\mathrm{T}_{1}\right)\end{array}$ & $\begin{array}{c}20.7 \pm \\
0.57\end{array}$ & $\begin{array}{c}21.9 \pm \\
0.44\end{array}$ & $\begin{array}{c}21.0 \pm \\
0.48\end{array}$ & $\begin{array}{c}22.56 \pm \\
0.34^{\mathrm{a}}\end{array}$ & $\begin{array}{c}25.13 \pm \\
0.25^{\mathrm{a}}\end{array}$ & $\begin{array}{c}25.95 \pm \\
0.13^{\mathrm{a}}\end{array}$ & $\begin{array}{c}29.30 \pm \\
0.47^{\mathrm{a}}\end{array}$ & $\begin{array}{c}23.14 \pm \\
0.27\end{array}$ & $\begin{array}{c}23.20 \pm \\
0.25\end{array}$ & $\begin{array}{c}22.45 \pm \\
0.18\end{array}$ & $\begin{array}{c}22.15 \pm \\
0.22\end{array}$ & $\begin{array}{c}21.77 \pm \\
0.11\end{array}$ & $\begin{array}{c}21.56 \pm \\
0.19\end{array}$ & $\begin{array}{c}23.13 \pm \\
0.30^{\mathrm{a}}\end{array}$ \\
\hline
\end{tabular}


Table.6 Plasma progesterone (ng/ml) Profile of black Bengal does

\begin{tabular}{|c|c|c|c|c|c|c|c|c|c|c|c|c|c|c|}
\hline \multirow[t]{2}{*}{ Group } & \multicolumn{13}{|c|}{ Days interval } & \multirow{2}{*}{$\begin{array}{c}\text { Mean } \\
\pm \\
\text { SEM }\end{array}$} \\
\hline & -90 & -75 & -60 & 45 & -30 & -15 & 0 & 15 & 30 & 45 & 60 & 75 & 90 & \\
\hline $\begin{array}{c}\text { Control } \\
\left(\mathbf{T}_{0}\right)\end{array}$ & $\begin{array}{c}11.27 \pm \\
0.37^{\mathrm{b}}\end{array}$ & $\begin{array}{c}12.11 \pm \\
0.32^{\mathrm{b}}\end{array}$ & $\begin{array}{c}13.06 \pm \\
0.39^{\mathrm{b}}\end{array}$ & $\begin{array}{c}13.22 \pm \\
0.83\end{array}$ & $\begin{array}{c}10.37 \pm \\
0.21^{\mathrm{b}}\end{array}$ & $\begin{array}{c}10.71 \pm \\
0.13^{\mathrm{b}}\end{array}$ & $\begin{array}{c}1.76 \pm \\
0.04\end{array}$ & $\begin{array}{c}1.29 \pm \\
0.05\end{array}$ & $\begin{array}{l}0.79 \pm \\
0.10^{\mathrm{b}}\end{array}$ & $\begin{array}{c}0.91 \pm \\
0.04\end{array}$ & $\begin{array}{l}0.72 \pm \\
0.04^{b}\end{array}$ & $\begin{array}{c}0.67 \pm \\
0.02\end{array}$ & $\begin{array}{c}0.46 \pm \\
0.02\end{array}$ & $\begin{array}{l}5.96 \pm \\
0.17^{\mathrm{b}}\end{array}$ \\
\hline $\begin{array}{l}\text { Treatm } \\
\text { ent }\left(T_{1}\right)\end{array}$ & $\begin{array}{c}14.52 \pm \\
0.14^{\mathrm{a}}\end{array}$ & $\begin{array}{c}14.51 \pm \\
0.11^{\mathrm{a}}\end{array}$ & $\begin{array}{c}14.03 \pm \\
0.20^{\mathrm{a}}\end{array}$ & $\begin{array}{c}14.16 \pm \\
0.28\end{array}$ & $\begin{array}{c}14.64 \pm \\
0.28^{\mathrm{a}}\end{array}$ & $\begin{array}{c}14.23 \pm \\
0.26^{\mathrm{a}}\end{array}$ & $\begin{array}{c}1.55 \pm \\
0.17\end{array}$ & $\begin{array}{c}1.43 \pm \\
0.07\end{array}$ & $\begin{array}{l}1.23 \pm \\
0.06^{\mathrm{a}}\end{array}$ & $\begin{array}{c}1.06 \pm \\
0.06\end{array}$ & $\begin{array}{l}0.82 \pm \\
0.02^{\mathrm{a}}\end{array}$ & $\begin{array}{c}0.72 \pm \\
0.02\end{array}$ & $\begin{array}{l}1.01 \pm \\
0.52\end{array}$ & $\begin{array}{l}7.22 \pm \\
0.17 \mathrm{a}\end{array}$ \\
\hline
\end{tabular}

*Values bearing different superscripts in column differ significantly $(\mathrm{P}<0.05)$ from each other

Fig.1 Plasma estradiol-17 $\beta(\mathrm{pg} / \mathrm{ml})$ in control (T0) and treatment (T1) at different intervals

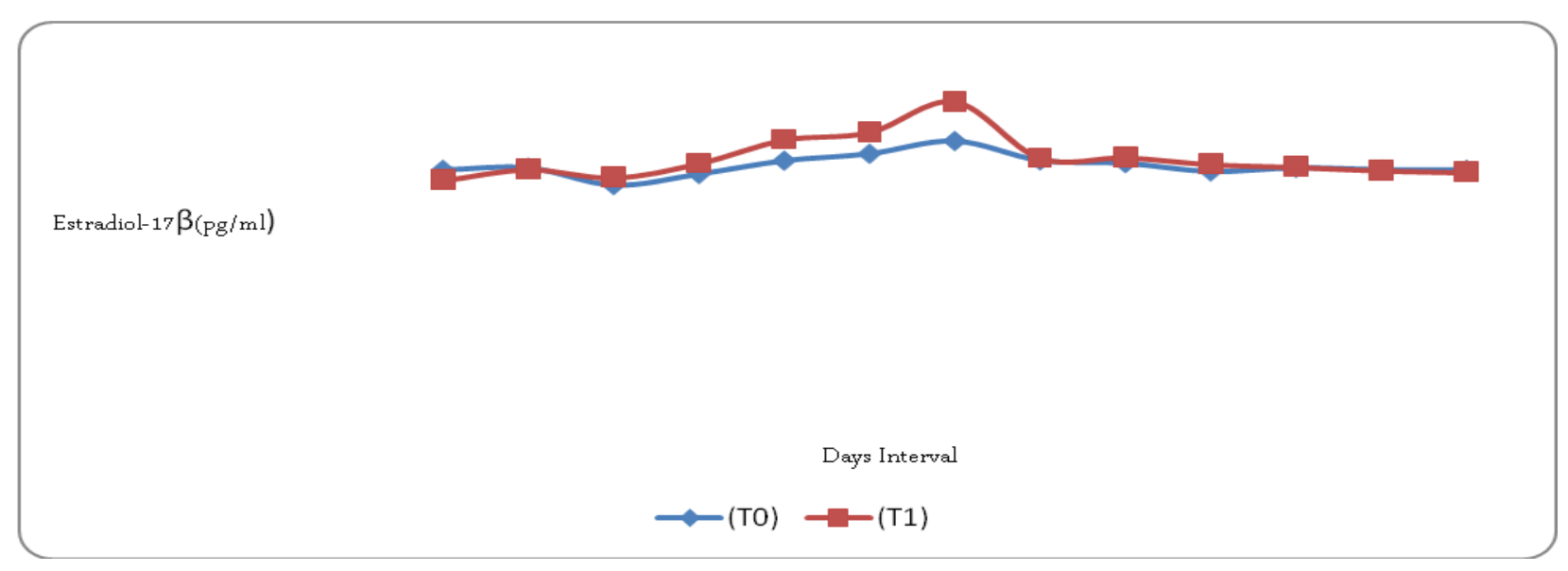

Fig.2 Plasma progesterone (ng/ml) in control (T0) and treatment (T1) at different intervals

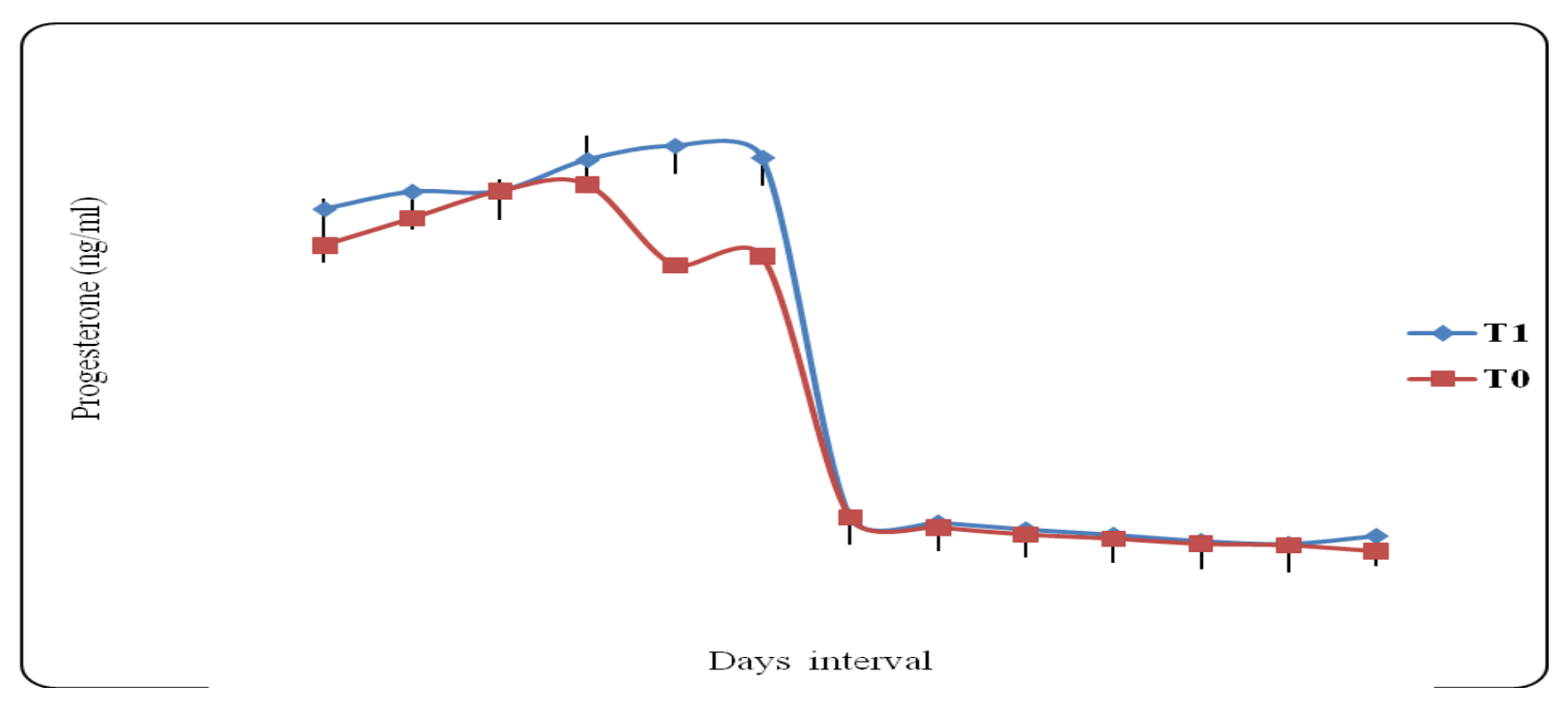

Influence of ASMM on Estradiol-17 $\beta$ level

Plasma Estradiol-17 $\beta$ level was higher in the
ASMM supplemented group during prepartum than in the control group after that it decreased gradually and maintained at basal 
level after 15 days of parturition. It differed significantly $(\mathrm{P}<0.05$; Table 5;Figure 1) before parturition, but after parturition did not show any effect. The overall mean of Estradiol-17 $\beta$ level differed significantly $(\mathrm{P}<0.05$; Table 5) between the groups. Verma (2015) reported that Estradiol-17 $\beta$ level was non- significantly $(\mathrm{P}>0.05)$ between the groups after the feeding of ASMM ( $\mathrm{Ca}, \mathrm{P}$, $\mathrm{Mn}, \mathrm{Zn}, \mathrm{Cu}$ and $\mathrm{Co}$ ) on a crossbred heifer. Copper has been a significant role in maintaining optimum fertility as it behaves in a regular way to be used as an indicator for estrogen activity (Desai et al., 1982). The role of $\mathrm{Zn}$ in enzymatic action (superoxide dismutase) involving reproductive functions has also been reported (Olson et al., 1999). Some evidence suggests that Mn plays an important role in the activity of certain endocrine organs. It is involved as a cofactor in cholesterol synthesis which is necessary for the synthesis of steroids like progesterone, estrogen and testosterone (Keen and Zidenburg-Cherr, 1990; Kapil and Zidenberg, 1999). Deficiency of steroid hormone production causes low circulating levels of these hormones causing sperm abnormality in males and abnormal estrus cycles in females. Decrease zinc level was correlated with a decrease in steroid hormone concentrations which showed some correlation between plasma zinc concentration and estrogenprogesterone levels for proper reproductive processes (Dutta et al., 2001). Bearden et al., (2004) reported that minerals have an important role in the activity of enzymes and hormones at the cellular level so its deficiency ultimately affects the reproductive efficiency of females.

\section{Influence of ASMM on progesterone level}

The overall mean value progesterone in control $\left(\mathrm{T}_{0}\right)$ and treatment $\left(\mathrm{T}_{1}\right)$ groups was $5.96 \pm 0.17$ and $7.22 \pm 0.17$, respectively and values differed significantly $(\mathrm{P}<0.05$; Table 6;
Figure 2) between the groups. The present study showed that blood progesterone level was higher in treatment $\left(\mathrm{T}_{1}\right)$ group compare to control $\left(\mathrm{T}_{0}\right)$ group till the day of parturition and interestingly after 45 days of parturition level of progesterone increased in the treatment group than the control group. This may be due to increased $\mathrm{Cu}, \mathrm{Zn}$ containing enzyme metalloproteinase -2 which is responsible for the synthesis of progesterone and estradiol. In the present study blood, $\mathrm{Cu}$ and $\mathrm{Zn}$ level was also observed higher. Some research found that $\mathrm{Mn}$ has an important role in the activity of certain organs. It is involved as a cofactor in cholesterol synthesis which is necessary for the synthesis of steroids like progesterone, estrogen and testosterone (Keen and Zidenburg-Cherr, 1990; Kapilet al., 1999). The corpus luteum has high Mn concentration and it may be influenced by the dose of Mn supplementation. Dutta et al., (2001) also reported that anestrus heifers are in deficient in zinc level. Decrease zinc level was correlated with a decrease in steroid hormone concentrations which showed some correlation between plasma zinc concentration and estrogen-progesterone levels for proper reproductive processes (Dutta et al., 2001). Bearden et al., (2004) reported that minerals have an important role in the activity of enzymes and hormones at the cellular level so its deficiency ultimately affects the reproductive efficiency of females.

From this study, it is concluded that areaspecific mineral mixture supplementation with concentrate has a beneficial effect on the reproductive performance of Black Bengal does. ASMM supplemented animals showed significant higher progesterone and estrogen concentration with an improvement of conception rate. Thus, ASMM supplementation showed overall improvement in reproductive performance of Black Bengal does. 


\section{Funding}

This study was sponsored by a research grant from ICAR-NDRI (Deemed University) India.

\section{Acknowledgements}

The authors thank ICAR-NDRI (Deemed University) India funding this research and especially for providing suitable experimental conditions.

\section{References}

Amin, M. R., Husain, S. S. and Islam, A. B. M. M. 2001. Reproductive peculiarities and Litter weight in genetic groups of Black Bengal does. Asian-Australian Journal Animal Science. 14: 297-301.

AOAC. 2005. Association of Official Analytical Chemists, Official Methods of Analysis. $18^{\text {th }}$ Edition., Maryland, USA.

Ballantine, H. T., Socha, M. T., Tomlinson, D. A. D., Johnson, A. B., Fielding, A. S., Shearer, J. K. and Van Amstel, S. R. 2002. Effects of feeding complexed zinc, manganese, copper, and cobalt to late gestation and lactating dairy cows on claw integrity, reproduction, and lactation performance. The Professional AnimalScientist.18 (3): 211-218.

Banerjee, G.C. 2004. A text book of Animal Husbandry. Oxford \& IBH Publishing Co. Pvt. Ltd. New Delhi. $8^{\text {th }}$ edition: 933-961.

Bearden, H. J., Fuquay. J. W. and Willard, S. T. 2004. Applied Animal Reproduction, Sixth Edition. Pearson Prentice Hall, Upper Saddle River, New Jersey, NY, U.S.A.

Bearden, H. J., Fuquay. J. W. and Willard, S. T. 2004. Applied Animal Reproduction, Sixth Edition. Pearson Prentice Hall, Upper Saddle River, New Jersey, NY,
U.S.A.

Desai, M. C., Thakkar, T. P., Dharshana, R. A. and Janakiraman, K. 1982. Serum copper and iron in Surti buffalo in relation to reproduction and gonadotropins [Indian breed]. Indian Journal of Animal Sciences. 102(1): 6276.

Dutta, A., Sarmah, B. C. and Baruah, K. K. 2001. Concentrations of serum trace element in cyclic and anoestrus heifers in lower Brahmaputra valley of Assam. Indian Veterinary Journal (India). 78: 300-302.

Ghosh, M.K., Chatterjee, A., Mondal, A., Das, S.K. and Dutta, T.K. 2013.Area specific mineral mixture (CALMINERS) for livestock in lower Gangetic region of West Bengal.

Hafez,E. J. H. 1962. Reproduction in Farm Animals. $5^{\text {th }}$ Edition., Lea and Febiger, Philadelphia, USA pp: 410-412.

Harrison J.P., Hancock D.D., and Conrad H.R. 1984.Vitamin E and selenium for reproduction in the dairy cow. Journal DairySciences.67: 123-32.

Husain, S. S. 1999. Sustainable genetic improvement of economic traits of Black Bengal goats through selective and crossbreeding. Bangladesh Agricultural University Research Progress. 10: 72-80.

Kapil, L.C. and Zidenberg, S. 1999. Manganese: Present Knowledge in nutrition, In: Brown ML (Ed.), International Life Sciences Institute Nutrition Foundation, Washington, Pp 308.

Keen, C. L. and Zidenberg-Cheer, S. 1990. Manganese. Pp: 279-268 In present knowledge in nutrition. M.L. Brown Ed. 32.International Life science Institute Nutrition Foundation Washington, D.C.

Kreplin, C., and Yaremcio, B. 1992. Effects of nutrition on beef cow reproduction. Agdex, 420: 51-1. 
Kumar, P., Sharma, M.C. and Joshi, C. 2005. Status of microminerals, hormone and vitamin profile in buffaloes (Bubalus bubalis) of Agra region of Uttar Pradesh. Indian Journal of Animal Research. 75(8): 909-914.

Olson, P. A., Brink, D. R., Hickok, D. T., Carlson, M. P., Schneider, N. R., Dentscher, G. H., Adams, D. C., Colbum, D. J. and Johnson, A.B. 1999. Effect of supplementation of organic and inorganic combination of copper, cobalt, manganese and zinc about nutrient requirement levels on postpartum two years old cows. Journal of Animal Sciences, 77: 522-532.

Sharma, M. C., Joshi, C. and Das, G. 2009. Soil, fodder and serum mineral (cattle) and haematobiochemical profile in some districts of Central Uttar Pradesh. Indian Journalof Animal Sciences.79(4): 411-415.

Smith, O. B. and Akinbamijo, O. O. 2000.Micronutrients and reproduction in farm animals. Animal Reproduction Science, 60: 549 -560.

Sultana, S., Khan, M., Hassan, M., and Khondoker, M. 2012. Effects of concentrate supplementation on growth, reproduction and milk yield of Black Bengal goats (Capra hircus). Bangladesh Veterinarian.29(1):

Underwood, E. J. and Suttle, N. F. 2003. Minerals in livestock nutrition. Third Edition. University of Florida, Gainesville.

Van Soest, P.J., Robertson, J.B. and Lewis, B.A. 1991. Methods for dietary fiber, neutral detergent fiber, and nonstarch polysaccharides in relation to animal nutrition. Journal DairySciences. 74: 3583-3597.

Verma, R.K. 2015.Effects of Supplementation of Area-Specific Mineral Mixture on Onset of Pubertal Process in Growing Crossbred Heifers. $M \quad V \quad S c$ thesis Animal nutrition, ICAR-National Dairy Research Institute, Karnal.

\section{How to cite this article:}

Kedare, G.M., Vipin, R.S. Mantri, A. Mandal, M. Karunakaran and Ghosh, M.K. 2020. Effect of Supplementing Area Specific Mineral Mixture on Reproductive Performance of Peripartum Black Bengal Goats. Int.J.Curr.Microbiol.App.Sci. 9(05): 569-576. doi: https://doi.org/10.20546/ijcmas.2020.905.064 